THE EFFECTS OF THE AGEING EUROPEAN POPULATION ON ECONOMIC GROWTH AND BUDGETS: IMPLICATIONS FOR IMMIGRATION AND OTHER POLICIES

\author{
Martin S. Feldstein \\ Working Paper 12736 \\ http://www.nber.org/papers/w12736 \\ NATIONAL BUREAU OF ECONOMIC RESEARCH \\ 1050 Massachusetts Avenue \\ Cambridge, MA 02138 \\ December 2006
}

The views expressed herein are those of the author(s) and do not necessarily reflect the views of the National Bureau of Economic Research.

(C) 2006 by Martin S. Feldstein. All rights reserved. Short sections of text, not to exceed two paragraphs, may be quoted without explicit permission provided that full credit, including $\odot$ notice, is given to the source. 
The Effects of the Ageing European Population on Economic Growth and Budgets: Implications for Immigration and Other Policies

Martin S. Feldstein

NBER Working Paper No. 12736

December 2006

JEL No. H2,H55,J61

\begin{abstract}
$\underline{\text { ABSTRACT }}$
The ageing of the population presents a major fiscal challenge for the countries of Europe. The combination of increased longevity and a reduced birth rate will directly reduce the growth rates of the European economies by slowing the growth of the capital stock and by weakening the productivity of the labor force. This slower growth of GDP means a smaller tax base and less tax revenue. In addition, the current tax-financed systems of social pensions and health care will require substantial increases in the already high tax rates. The analysis in this paper shows that the common prescription of increased immigration would do little to reduce the future fiscal burden. The increased revenue from a large rise in immigration would finance only a small part of the coming rise in the cost of pension and health benefits. The only alternative to significantly higher tax rates or substantially lower retirement income is to shift from a pure tax-financed system to a mixed system that supplements the tax financed benefits with benefits based on increased saving financial investment.
\end{abstract}

Martin S. Feldstein

President and Chief Executive Officer

NBER

1050 Massachusetts Avenue

Cambridge, MA 02138-5398

and NBER

msfeldst@nber.org 


\title{
The Effects of the Ageing European Population on Economic Growth and Budgets: Implications for Immigration and Other Policies
}

\author{
Martin Feldstein*
}

Medical science and changes in personal behavior have extended life expectancy and will continue to do so in the years ahead. A variety of social changes have led to reduced birth rates. The result has been an increasing relative number of older persons in the population and a slower rate of growth of the population and of the labor force. These trends will continue in the future, perhaps at an accelerating rate.

Some European countries are beginning to experience an actual decline in the total size of the population and of the labor force. Even where that has not occurred, the size of the labor force has been growing more slowly than the total size of the population, causing a reduction in the ratio of employees to total population. In Spain, for example, the official United Nations projections show the total population will remain essentially unchanged over the next 50 years while the number of workers per retiree will fall sharply from 4.5 today to fewer than 2 in 2050 .

The aging population will cause substantial increases in the cost of the current government pension and health care programs. In Spain, the cost of the Social Security pensions is projected officially to nearly double over the next 50 years, rising from 8.4 percent of GDP

*Professor of Economics, Harvard University, and President and CEO of the National Bureau of Economic Research. An earlier version of this paper was presented at the $20^{\text {th }}$ International Conference of Private Business Organizations in Madrid, Spain on 19 October 2006. 
now to a projected 15.7 percent of GDP in 2050. Over this same period, health care is projected to rise from 6 percent of GDP to a bit more than 8 percent of GDP - presumably because of assumed tough government expenditure controls that outweigh the natural consequence of an aging population and rapidly improving medical technology.

This paper discusses the ways in which governments can respond to these budget problems with particular attention to the proposal to use increased immigration to offset the slow growth or decline of the native labor force. Before doing so, the paper begins by examining some of the direct economic consequences of the aging population and the resulting slowdown of population growth.

\section{Direct Effects of Slower Population Growth on Per Capita Incomes}

Of course, slower growth of population implies a smaller labor force and therefore a smaller level of total gross domestic product. But the size of the national economy is much less important than the level of per capita income because it is per capita income that affects the standard of living. The adverse effect of the slower population growth on per capita income and therefore on the standard of living is therefore the focus of this section.

As I will explain, slower population growth depresses the rate of saving and therefore reduces the volume of business investment in productivity-enhancing equipment and structures. Slower population growth also reduces productivity by its effect on the quality of the labor force. The cumulative effect of both of these can be quite significant unless policy measures are taken to offset them.

Consider first the effect of slower population growth on the national saving rate. At any 
point in time, there are some households that are savers (i.e., consuming less than their entire after-tax income) and other households that are dissavers (borrowing or using up some of their previous saving). The savers are predominantly middle aged employees who are preparing for retirement. The dissavers are typically in their retirement years. In a growing economy there are relatively more middle-aged savers than there are older dissavers. That, together with rising per capita income, is what causes the saving of the savers to be greater than the dissaving of the dissavers. That difference between the saving and the dissaving creates a positive saving rate for the economy as a whole. The faster the population growth rate, the higher will the nation's saving rate tend to be. That explains why the aging of the population and the slower rate of population growth cause a decline in the share of national income that is saved.

This lower rate of saving will in turn lead to a lower rate of investment in business plant and equipment. Although in principle Spain could in the future supplement its lower saving rate by importing capital from other countries, this is not likely to happen in practice for two different reasons. First, the other industrial countries are also experiencing slower population growth and that will cause their saving rates to decline. So they too would want to import capital and would not be in a position to shift capital to Spain. Moreover, experience shows that, over sustained periods of time, industrial countries invest what they save at home. So even countries with higher saving rates will tend to keep the extra saving at home.

The lower level of investment in plant and equipment reduces the capital intensity of the economy and therefore reduces the productivity of employees and the overall level of national income. In addition, a lower rate of business investment causes a lower rate of introduction of new technology which further reduces the growth of productivity. 
An aging work force also lowers productivity growth directly. We know from experience that each generation of employees earns more than the previous generation. One reason for this is the improved level of education and of skills that the new generation brings to work. We are all aware of the greater facility that younger workers generally have in using computers and the internet. Younger workers also generally learn new skills more readily. So an aging workforce means lower increases in productivity from this source as well.

In short, the aging of the population that results from the combination of increased longevity and a reduced birth rate will directly reduce the growth rate of the economy by slowing the growth of the capital stock and by weakening the productivity of the labor force. These problems are made worse by the budget impact of the aging population, the subject to which I now turn.

\section{Economic Consequences of the Budget Effects of the Aging Population}

The governments of most industrial countries provide pensions and health care to older residents. The costs of the pension programs rise proportionately with the number of older persons, implying that these costs will rise faster than GDP as the ratio of older individuals to the number in the working age population increases. Health care costs of the aged rise even faster than the number of older persons because the health costs are relatively greater for the "old-old" and that group is growing relatively faster than the total number of aged.

The rising cost of pensions and of health care for the aged directly increase the government's budget outlays when these programs are financed on a pay-as-you-go basis, as they are now in the United States and in most other major industrial countries. Although these costs 
can be financed temporarily by borrowing or selling government assets, on a sustained basis these costs can only be financed by higher taxes.

The increase in tax rates needed to finance the higher costs that result from an aging population will be very large indeed unless there is some change in benefits or in the financing of these programs for the aged so that they do not have to rely exclusively on pay-as-you-go tax finance. Before looking at such alternatives, consider the magnitude of the tax increase that would be required.

In the United States, a county in which the future demographic change will be smaller than the change in Europe and Japan, the payroll tax that is used to finance Social Security pension benefits would have to rise from about 12 percent now to about 20 percent by 2030 . As a fraction of GDP, this would represent a rise from about 5 percent to about 8 percent. In the typical European country the rise in taxes would be even greater because of the greater generosity of the existing benefits and the greater increase in the ratio of the number of retirees to the number of working persons. In Spain, social security pensions already take 8.4 percent of GDP and that is projected to nearly double to 15.7 percent of GDP by 2050 .

These implied large tax increases would have major adverse effects on any economy. Consider the effect of higher payroll taxes. In the short run, the portion of these taxes paid by employers would cause a reduction in hiring and in employment. Over time, the payroll taxes would be shifted to employees in the form of lower hourly wages. Such a reduction in wage rates would reduce the growth of pretax incomes in many ways. The most direct way would be shortening the number of hours per year that employees want to work. We already see this in the comparison of European and US working hours with Europeans having longer vacations and 
fewer average working hours per week. Two earner couples are also less common in Europe than in the United States. I believe that high marginal tax rates on labor income are a major reason for these differences.

The reduction in working hours reduces output and total labor income. This in turn means that tax rates have to be even higher to finance the projected rise in benefits.

Fewer working hours are only one part of the adverse effect of higher tax rates on the supply of labor in the economy. Individuals respond to higher marginal tax rates by choosing occupations that pay less but that are also more pleasant or less onerous. High marginal tax rates also discourage the acquisition of new skills through formal education and on the job training. And high marginal tax rates reduce the effort that employees bring to the job. Why work harder when the government is going to take a large share of the reward for that extra effort? And why take the risks associated with entrepreneurial activities when the extra gains will be subject to high tax rates?

So in all of these ways the high marginal tax rates that would result from using taxes to finance the current benefits as the population ages would cause a reduction in national income and in economic growth.

The need to finance the increased pension and health benefits of an aging population would also result in greater taxes on business profits and on household income from savings, i.e. on dividends, interest, and capital gains. Such taxes would be a further burden on the economy and on economic growth. High taxes on investment income reduce the incentive for firms to invest in new plant and equipment. Multinational firms can also shift investment to other countries. High taxes on the return to saving - i.e. higher taxes on dividends, interest, and capital 
gains - cause households to shift consumption to the present from the future. And the specific forms of capital taxation often shift capital from more productive uses to investments like housing that do much less to raise national income and economic growth.

Avoiding these tax increases requires making fundamental changes in the level of benefits or the way that benefits are financed. In the United States, avoiding an increase in the taxes to finance pension benefits would require cutting projected benefits by about one-third over the next twenty years or so and keeping benefits at this relatively depressed level. The required reductions in health care spending on the aged would have to be even larger. Such a large reduction would cause financial hardship for many of the aged and would require fundamental reductions in the level of medical care. I think neither of these changes is likely to occur.

That is why many countries are thinking about or actually adopting a new approach to financing pension benefits for the aged. That new approach involves introducing an investment based component alongside the tax-financed benefits. In that way, benefits can be maintained while higher tax rates are avoided.

Before talking about how such reforms can work in practice, I want to talk about two other possibilities that are frequently discussed: increasing immigration and reducing spending on other forms of government activity, particularly national defense spending.

\section{Increasing Immigration}

Much of the discussion of the aging population that one hears in Europe involves a call for increased immigration as a possible policy response. It is easy to understand how people are drawn to this conclusion. If a low birth rate leads to slow population growth and health 
improvements lead to an aging population, why not increase the immigration of young and middle aged workers? That will reduce the average age of the population and increase the rate of population growth. Although there is general discomfort with some of the social consequences of increased immigration, many people have concluded that increased immigration is the "only way" to avoid a major increase in tax rates or a major cut in benefits.

The presumed advantage of increased immigration as a policy response to the aging population is that it would help to finance the benefits of the aged. The contribution of the immigrants to their new host country is that they pay taxes. It is not the work of the immigrants or their income that matters for this purpose but their role as taxpayers.

But while this case for increased immigration seems plausible, a little reflection on the magnitude of the fiscal effect of increased immigration shows that a very large increase in immigration would have only a very small impact on the revenue needed to deal with the aging population.

In any market economy, the additional output that the new immigrants produce goes either to them in the form of wages or to the government in the form of payroll taxes. The immigrants would also pay income taxes and value added taxes. But not all of that additional tax revenue is available to help finance the benefits of the existing ("native") aging population. Some of the tax revenue generated by the immigrants is needed to finance the benefits that they themselves consume - especially health care and education.

It is necessary therefore to ask how much net revenue is created by immigration to finance the benefits of the existing aged and how that additional revenue relates to the size of the increased number of immigrants. My calculations indicate that the extra revenue is not large 
relative to the increased number of immigrants. I wonder just how many of those who advocate increased immigration as the response to the aging population have calculated how little additional net revenue is achieved by a substantial increase in immigration. Stated differently, the increased revenue from a large rise in immigration would finance only a small part of the coming rise in the cost of pension and health benefits.

Here are some simple back of the envelope calculations for Spain. The analysis would be much the same for other European countries. An inflow to Spain of an additional 2 million new immigrants of working age would be equivalent to a 10 percent increase in the size of Spain's labor force. If the increased immigration could be limited just to those who enter employment, that would be equivalent to a 54 percent increase in the size of the foreign population in Spain. Of course, some of these immigrants would bring dependents with them, making the rise in the immigration population more than the 2 million workers.

A rise of more than 50 percent in the number of immigrants in Spain would have a major impact on social and political conditions. What would it mean in terms of additional tax revenue?

Since immigrants generally earn less than "native" Spanish employees, a rise in the number of immigrants equal to 10 percent of the labor force would probably cause the total labor compensation to rise by about 8 percent or less. And since wages are only about 75 percent of total GDP, a rise of 8 percent in gross wages would be equivalent to a 6 percent rise in the size of GDP.

Although taxes would take some of this additional gross wage income, at least half of the 
additional 6 percent of GDP would be consumed by the immigrants and their families. An additional fraction of the 6 percent extra GDP would be used by governments to finance benefits for the immigrants and their families - health benefits, education benefits, unemployment compensation, and eventually retirement benefits. So the net additional benefits available to pay benefits of the native population would be only about 2 percent of GDP or less.

This 2 percent of GDP is very small relative to the cost of providing social benefits to the future Spanish population. Government spending on Social Security pensions and health care is now 14 percent of GDP and is project to rise by 2050 to 24 percent of GDP. The 2 percent of GDP in net revenue that would result from a 50-plus percent rise in the number of immigrants in the population would therefore finance less than 10 percent of the projected pension and health benefits.

Another way to look at this is to note that reducing the growth of benefits by less than one tenth of their projected level would provide as much fiscal relief as a 50-plus percent increase in the number of immigrants.

If pension benefit rules are modified so that total Social Security pensions rise from today's 8.4 percent of GDP to 13.7 percent of GDP in 2050 instead of the currently projected 15.7 percent, the savings would be as great or greater than the net revenue effect of 2 million additional immigrant workers and their families.

It is clear from this calculation that an increase in the number of immigrants would not solve the financing problem facing the Spanish economy in the coming years. The increased immigration would moreover provide only a temporary fiscal relief to a permanent demographic problem. The aging of the Spanish population and the slower rate of growth of the population 
will persist in the long term. The extra immigrants who might arrive in the next decade would provide more revenue temporarily but would eventually receive retirement pensions and health care that absorb the extra taxes that they pay. It would take a continuing increase in the number of immigrants to achieve even the relatively small additional revenue that I have described.

Whether or not this use of increased immigration to raise additional short term revenue is a favorable trade-off - i.e., whether the nation would be better off with a relatively small reduction of benefit growth or a relatively large increase in the number of immigrants - is a political decision that Spain and every other country must make for itself.

There may also be other reasons to favor increased immigration. The new immigrants would certainly enjoy an improved standard of living for themselves, their children and their descendants. But it would be wrong to advocate increased immigration as a policy that is needed to deal with the aging of the population or even as one that could successfully avoid large future tax increases or benefit reductions.

\section{$\underline{\text { Redirecting Budget Outlays }}$}

An alternative to raising taxes, reducing the benefits of the aged, or increasing immigration would be to reduce some other forms of government spending and to redirect those budget funds to the programs for the aged. There are many ways in which government outlays could be reduced without hurting the economy. Every country could benefit from reducing subsidies to inefficient industries or low productivity agriculture. Such changes would be desirable even if there were not a new problem of reduced tax revenue and increased benefits due to the aging of the population. 
But the policy debates in Europe do not indicate much likelihood of significant reductions of government outlays. Indeed, much of the talk about the Lisbon agenda has induced European governments to find new ways to increase government spending in the hope of raising the growth of productivity.

The major exception to this reluctance to cut government spending is the idea that reducing defense spending may be an appropriate response to the fiscal problem of the aging population. Although much could be done to make defense outlays more efficient, the small size of current defense budgets implies that reduced defense outlays would do little to deal with the fiscal problem of the aging economy. Cutting defense budgets in half would finance only about one tenth of the increased fiscal cost caused by the aging of the population.

Reducing defense spending in the coming years would create other problems. NATO is currently struggling in Afghanistan to find sufficient troops and firepower to deal with the Taliban. The terrible terrorist incidents in Madrid and London remind us of the increased threat of domestic terrorism. More funds for defense and for intelligence activities are going to be needed in the years ahead just to maintain the current level of national security.

\section{Mixed Financing of Pension and Health Benefits}

There is, fortunately, another way to avoid the future tax increase without cutting future retiree incomes. Shifting from the current pure pay-as-you-go tax financed systems of pensions and health care to financing based on a combination of taxes and financial investments could reduce the burden on future generations of employees and taxpayers without lowering the standard of living of future retirees. 
I will focus on how such a mixed system could be used to deal with the increasing cost of pensions. A similar approach could help to finance the increased health costs of the aged.

Avoiding the currently projected large tax increase to finance benefits for the aged would require limiting the future tax-financed benefits. But in a mixed system those tax financed benefits would be supplemented by investment based benefits - i.e., benefits that would be generated by saving and investing those savings in stocks and bonds.

Several countries have already pursued this approach. The specific ways that they have done so differ from country to country, depending on local political preferences and economic conditions. The most common form is to divide the social security payroll taxes into a portion that is used by the government to pay tax-financed benefits and a separate portion that the individual can direct to a mutual fund or a bank or an insurance company where those funds are invested. When the individual reaches retirement age, he or she receives both a tax-financed pension and an additional pension based on the value of the assets that the individual has accumulated in the investment-based account. Such mixed systems for financing pension benefits have been adopted by such diverse countries as Sweden, England, Australia, Mexico and China.

Although a mixed system can avoid the very large tax increase that would be needed with a pure tax-financed pay as you go system in order to maintain the current relative level of benefits, it is not costless. Some additional saving must be done to fund the individual accounts. But because the rate of return on an investment based account is much greater than the implicit return in a pure tax-financed system, the amount of saving that is needed is much less than the amount of additional taxes that would otherwise be required. The required amount of savings 
depends on the demographic projections and the investment strategy. Detailed calculations for the United States based on the assumption that the savings are invested in a mixture of 60 percent equities and 40 percent bonds indicate that the tax increase equal to nearly 10 percent of taxable wages that would be required with a pure pay-as-you-go system could be replaced by new savings of 2 percent of the same wage base.

While a mixed system avoids the near certainty of benefit cuts in the future, the investment based component does of course involve some risk. The amount of the risk depends on the mix of stocks and bonds in which the extra saving is invested. Countries that adopt this approach generally require that the investments are made in broad-based mutual funds rather than in individual stocks or narrow industry-specific funds. Some countries restrict the proportion of equities in the investment funds. It is also possible to provide guarantees that limit the risk that an individual would receive a pension below some desired amount. These guarantees could be provided by the government or by the financial markets.

\section{$\underline{\text { Conclusion }}$}

The ageing of the population presents a major fiscal challenge for the countries of Europe. Continuing the current tax-financed systems of social pensions and health care will require substantial increases in the already high tax rates. The analysis in this paper shows that the common prescription of increased immigration would do little to reduce the future fiscal burden. The only alternative to significantly higher tax rates or substantially lower retirement income is to shift from a pure tax-financed system to a mixed system that supplements the tax financed benefits with benefits based on increased saving and financial investment. 
Cambridge, MA

November 2006 